\title{
PERAN DINAS SOSIAL PEMBERDAYAAN PEREMPUAN DAN PERLINDUNGAN ANAK DALAM PEMBINAAN ANAK JALANAN DI RUMAH SINGGAH DUKUH SEMAR KOTA CIREBON
}

\author{
Siti Naelu Sa'adah ${ }^{1}$, Asep Mulyana ${ }^{2}$ \\ IAIN Syekh Nurjati Cirebon ${ }^{1,2}$ \\ nailussaadah50@gmail.com; asepmulyana@gmail.com
}

\begin{abstract}
Abstrak
Dinas Sosial Pemberdayaan Perempuan dan perlindungan Anak melakukan pembinaan untuk memajukan generasi bangsa salah satunya pembinaan anak jalanan di Rumah singgah Dukuh semar Kota Cirebon, akan tetapi menurut pengetahuan dan tanggapan dari penulis, implementasi dari program pembinaan anak jalanan di Dukuh semar kurang berjalan maksimal sehingga sangat dikhawatirkan anak jalanan bertingkah diluar kendali mereka karna anak jalanan sangat rentan dalam permasalahan sosial seperti terkena obat-obatan terlarang, pergaulan bebas, atupun melakukan tindakan kriminal. Tujuan peneliti ini untuk mengetahui program, proses dan peran pembinaan anak jalanan oleh Dinas Sosial Pemberdayaan Perempuan dan Perlindungan Anak di Rumah singgah Dukuh semar Kota Cirebon. Penelitian ini berbentuk deskriptif kualitatif menggunakan studi kasus. Teknik pengumpulan data menggunakan observasi, wawancara, dokumentasi dan triangulasi. Hasil penilitian ini yaitu programnya sangat bagus untuk memajukan generasi anak dan bangsa, proses dari implementasi program tersebut masih kurang berjalan secara maksimal karena Dinas sosial pemberdayaan perempuan dan perlindungan anak tidak rutin setiap minggu dalam pembinaan anak jalanan di Rumah singgah Dukuh semar Kota Cirebon, sehingga secara keseluruhan peran Dinas sosial dalam pembinaan anak jalanan di Dukuh semar masih kurang maksimal.
\end{abstract}

\section{Kata Kunci: Peran, Pembinaan, Anak Jalanan}

\begin{abstract}
Social agency ministry of woman empowerment and child protection are building for increasing nation generation one of ways are building street children in home stay Dukuh Semar Cirebon, but based on knowledge and writer's response, implementation from building program street children Dukuh Semar Cirebon not running well it's so worried. Street children loss their control because street children is very weak in the social problem such as drug, criminal acts, promiscuity. The purpose of research are for knowing program, process and the role of the development of street children. From social agency ministry of woman empowerment and child protection in home stay dukuh semar cirebon this research is descriptive, qualitative using study case, the data collection are observation, interview, documentation and tringulasi. The result is pretty good
\end{abstract}


program for increasing children generation and nation generation the process of implementation that program still not running well because social agency not routine Evey week in the building street children in home stay dukuh semar cirebon, so that way overall the role social agency in the building street children still not running well.

Keywords : the role, building, street children

\section{A. PENDAHULUAN}

\section{Latar Belakang Masalah}

Fenomena anak jalanan merupakan isu global di Indonesia, permasalahan sosial anak jalanan tidak asing lagi di kota-kota besar seperti Jakarta, Bandung begitu juga kota kecil seperti Cirebon. Fenomena merebahnya anak jalanan di Cirebon merupakan permasalahan sosial komples. Hidup menjadi anak jalanan memang bukan pilihan yang menyenangkan dan terkadang keberadaannya tidak jarang menimbulkan permasalahan sosial, membuat masyarakat sekitar beranggapan bahwa anak jalanan itu selalu membawa masalah, tanpa kita sadari mereka itu sebagian dari saudara kita yang kurang bernasib baik seperti kita, seharusnya kita bersyukur memiliki kehidupan yang lebih baik dari mereka. Wujud dari rasa bersyukur kita seharusnya membuka mata tentang anak jalanan untuk membangun rasa keperdulian yang tinggi, untuk melindungi dan tidak membedakan kedudukan anak jalanan dengan kita, mereka sama dengan kita amanah Allah SWT yang mempunyai hak untuk berkembang kehidupannya yang lebih baik lagi. Hak asasi anak merupakan bagian dari hak asasi manusia sebagaimana yang tercantum dalam UUD 1945, UU No.36 tahun 1990 tentang pengesahan Convention on the right of the child (Konvensi tentang hak-hak anak).

Masalah-masalah sosial pada dasarnya mengarah perhatiannya pada kondisi ketidak seimbangan prilaku, moral, dan nilai-nilai sosial. Hal ini diartikan sebagai suatu kehidupan masyarakat yang sebelumnya normal menjadi terganggu, sebagai akibat dari perubahan pada unsur-unsur kepentingan manusia dalam masyarakat. Masalah sosial itu mungkin berupa kebutuhan-kebutuhan sosial atau juga kebutuhan biologis. Masalah kebutuhan sosial disebabkan oleh ketidak seimbangan pergaulan dalam masyarakat, 
sedangkan masalah biologis disebabkan sulit atau tidak bisa lagi terpenuhi, seperti kebutuhan makan, minum dan sebagainya.

Masalah-masalah yang diakibatkan anak jalanan di kota Cirebon, cukup memprihatinkan dan sangat dihawatirkan menimbulkan keresahan lingkungan, sehingga Dinas Sosial Pemberdayaan Perempuan dan perlindungan Anak melakukan pembinaan-pembinaan terhadap anak jalanan dengan beberapa titik binaan di antaranya yaitu Dukuh semar, Empang, Pegambiran, Cangkol, Tanggul, Kriyan, dan Samadikun. Akan tetapi peneliti disini akan membahas sekitar titik binaan di Dukuh semar. Dinas Sosial Pemberdayaan Perempuan dan Perlindungan Anak itu memiliki pogram yang sangat bagus untuk memajukan generasi bangsa di antaranya pembinaan terhadap anak jalanan di Dukuh semar, akan tetapi menurut pengetahuan dan tanggapan dari penulis, implementasi dari program pembinaan anak jalanan di Dukuh semar kurang berjalan maksimal dikarenakan keterbatasan dalam pembinaan anak jalanan seperti keterbatasan tenaga pembina ataupun keterbatasan sarana dan prasarana dalam pembinaan sehingga implementasinya kurang berjalan secara maksimal sehingga sangat dikhawatirkan anak jalanan bertingkah diluar kendali mereka karna anak jalanan sangat rentan dalam permasalahan-permasalahan sosial seperti terkena obat-obatan terlarang, pergaulan bebas, atupun melakukan tindakan kriminal.

Atas dasar latar belakang diatas penulis tertarik untuk melakukan penelitian lebih lanjut dengan judul: "PERAN PEMBINAAN ANAK JALANAN DINAS SOSIAL PEMBERDAYAAN PEREMPUAN DAN PERLINDUNGAN ANAK DI RUMAH SINGGAH DUKUH SEMAR KOTA CIREBON"

\section{Rumusan Masalah}

Berdasarkan latar belakang masalah di atas, maka masalah dalam penelitian ini dapat dirumuskan sebagai berikut:

a. Bagaimana program pembinaan anak jalanan oleh Dinas Sosial Pemberdayaan Perempuan dan Perlindungan Anak di Dukuh Semar Kota Cirebon? 
b. Bagaimana proses pembinaan anak jalanan oleh Dinas Sosial Pemberdayaan Perempuan dan Perlindungan Anak di Dukuh Semar Kota Cirebon?

c. Bagaimana peran pembinaan anak jalanan oleh Dinas Sosial Pemberdayaan Perempuan dan Perlindungan Anak di Dukuh Semar Kota Cirebon?

\section{Tujuan Penelitian}

Berdasarkan permasalahan yang ada maka tujuan penelitian ini adalah sebagai berikut:

a. Mengetahui program pembinaan anak jalanan oleh Dinas Sosial Pemberdayaan Perempuan dan Perlindungan Anak di Rumah singgah Dukuh semar Kota Cirebon.

b. Mengetahui proses pembinaan anak jalanan oleh Dinas Sosial Pemberdayaan Perempuan dan Perlindungan Anak di Rumah singgah Dukuh semar Kota Cirebon.

c. Mengetahui peran pembinaan anak jalanan oleh Dinas Sosial Pemberdayaan Perempuan dan Perlindungan Anak di Rumah singgah Dukuh semar Kota Cirebon.

\section{B. KAJIAN TEORI}

\section{Pengetian Peran}

Para ahli sosiologi adalah membedakan peranan atas dua aspek yakni sebagai serangkaian "harapan" dan "penampilan" peranan yaitu tingkah laku yang sesungguhnya dari individu dalam menjalankan peranannya, jadi dapat diartikan peranan-peranan itu adalah produk sosial (bersifat sosial) dan "penampilan dari peranan "bersifat individual, dan karena itu berada di luar ruang sosiologi. (David Berry, 2003: 123).

\section{Pengertian Pembinaan}

Menurut Musanaf menyatakan bahwa pembinaan adalah segala usaha tindakan yang berhubungan langsung dengan perencanaan, penyusunan, pembangunan, pengembangan, pengarahan, penggunaan serta pengendalian segala sesuatu secara berdaya guna dan berhasil guna. (Musanaf, 2000: 47) 
Menurut Toha pembinaan adalah suatu proses, hasil atau pertanyaan menjadi lebih baik dalam hal ini mewujudkan adanya perubahan, kemajuan, peningkatan, pertumbuhan, evaluasi atau berbagai kemungkinan sesuatu. (Miftah Toha, 2001: 7)

\section{Definisi Anak Jalanan}

Anak jalanan didefinisikan sebagai individu sampai batas usia 18 tahun dan menghabiskan sebagian waktunya di jalan, pasar, terminal, lampu merah atau tempat umum lainnya baik untuk bermain ataupun untuk mencarri nafkah. Di antara mereka masih memiliki orang tua atau wali yang berkewajiban merawat mereka, namun demikian kebiasaan, nilai-nilai, dan jaringan interaksinya sebagian besar tumbuh dan berkembang dijalanan. Mereka memiliki sudut pandang yang berbeda dengan anak sebayanya yang hidup dalam lingkungan standar, mereka menerapkan diri sebagai orang yang memiliki tanggung jawab mencari nafkah, membiayahi kebutuhan sekolah saudaranya, dan berperan sebagai pimpinan kelompok yang harus menjaga kelompoknya. (Atwat Bajari, 2012: 6)

\section{Pengertian Lembaga Sosial dan Fungsinya}

Soelaiman Soemardi dalam buku Abdulsyani, menyatakan bahwa bahwa lembaga atau social instution sebagai "lembaga kemasyarakatan". kata lembaga dianggap tepat, oleh karena kecuali menunjukan pada suatu bentuk, juga mengandung pengertian abstrak tentang adanya kaidah-kaidah. Lembaga itu mempunyai tujuan untuk mengatur antara hubungan yang diadakan untuk memenuhi kebutuhan manusia yang paling penting. (Abdulsyani, 2012: 7576). Jadi Dinas sosial atau lembaga sosial adalah suatu lembaga yang didalamnya terdapat struktural atau pekerja-pekerja sosial dan mempunyai keteraturan dalam pemerintahan sosial dengan tujuan untuk mensejahterakan masyarakat, membangun masyarakat dan kepentingan umum lainnya yang berkaitan dengan kemasyarakatan. Dengan struktur sosial, maka secara psikologis anggota masyarakat merasa ada batasan-batasan tertentu dalam setiap melakukan aktivitas individu senantiasa menyesuaikan diri dengan ketertiban dan keteraturan masyarakat yang ada. 


\section{Pemberdayaan Perempuan}

Pembedayaan perempuan adalah usaha sistematis dan terencana untuk mencapai kesetaraan dan keadilan gender dalam kehidupan keluarga dan masyarakat, pemberdayaan perempuan sebagai sumber daya insan, potensi yang dimiliki perempuan dalam hal kuantitas ataupun kualitas tidak dibawah laki-laki. Upaya pemberdayaan perempuan dalam semangat perspektif gender memang tetap harus dilakukan dan juga tidak dapat dilakukan dan dibebankan hanya pada satu kementrian, tetapi harus dilakukan dan dikawal bersama dengan tekad memperdayakan perempuan adalah memberdayakan bangsa, bukankah dari ibu yang sehat akan lahir anak yang sehat, dan keluarga yang sehat. Bukan dari keluarga yang cerdas akan melahirkan anak yang cerdas juga. Di Indonesia strategi pemberdayaan perempuan dilakukan secara bertahap. Hal ini tampak dari progam keluarga berencana (KB) dengan memberikan kesempatan yang lebih besar kepada kaum ibu dan keluarga pada umumnya untuk mengurangi beban yang dipikulnya dalam lingkungan keluarga dengan mengetahui kehamilan dan kelahiran anak-anaknya, dengan cara itu, perempuan dapat berpartisipasi dalam pembangunan. Lebih dari itu, kaum ibu dapat ikut serta membangun keluarga, lingkungan serta gerakan pemberdayaan ekonomi keluarga. (Haryanto Suyono, 2003: 37)

\section{Perlindungan Anak}

Menurut Arif Gosita dalam buku Maidin Gultom berpendapat bahwa perlindungan anak adalah suatu usaha melindungi anak dapat melaksanakan hak dan kewajibannya. Perlindungan hak-hak anak pada hakikatnya menyangkut langsung pengaturan dalam menjamin terwujudnya perlindungan hak-hak anak, pertama-tama didasarkan atas pertimbangan bahwa anak-anak merupakan golongan yang rawan dan dependent, disamping karena adanya golongan anak-anak yang mengalami hambatan dalam pertumbuhan dan perkembangannya baik rohani, jasmani, dan sosia. (Maidim Gultom, 2014: 42) 


\section{METODOLOGI}

\section{Jenis Penelitian}

Penelitian ini berbentuk deskriptif kualitatif dengan menggunakan metode studi kasus. Dimana penelitian ini berusaha untuk menjawab pertanyaan sebagaimana di atas yaitu Peran Pembinaan Anak Jalanan Dinas Sosial Pemberdayaan Perempuan dan Perlindungan Anak di Rumah Singgah Dukuh Semar Kota Cirebon.

Deskriptif kualitatif adalah suatu jenis penelitian di mana peneliti akan menjelaskan atau mendeskripsikan dengan jelas apa hasil dari penelitiannya di lapangan melalui pengumpulan data diantaranya yaitu, observasi, wawancara, dokumentasi dan triangulasi.

Robet Yin berpendapat bahwa studi kasus merupakan penelitian dengan menggunakan strategi dalam pendekatan alamiah (inquiry) untuk menjawab pertanyaan tentang bagaimana dan mengapa kasus itu terjadi. Menurut Robert Stage, objek dari studi kasus adalah realitas kehidupan nyata yang mempunyai batasan-batasan yang jelas dan bersumber dari berbagai macam peristiwa. (Bambang Rustanto, 2015: 28)

\section{Waktu dan Tempat Penelitian}

Tempat penelitian ini adalah Rumah Singgah di Dukuh Semar Kota Cirebon. Subjek peneliti adalah Dinas Sosial Pemberdayaan Perempuan dan Perlindungan Anak, pembina anak jalanan, anak jalanan dan masyarakat sekitar anak jalanan Dukuh semar. Adapun alamat lengkap Rumah singgah Dukuh semar yaitu di Rt 9 Rw 3, gang sekat pandan titik binaan Dukuh semar, kelurahan Kecapi, kecamatan Harjamukti Kota Cirebon. Waktu penelitian 30 November 2017 sampai dengan 30 Januari 2018.

\section{Subjek Penelitian}

Dalam penelitian ini yang menjadi subjek adalah Dinas Sosial pembeberdayaan perempuan dan Perlindungan Anak, Pembina dan anak jalanan Dukuh semar. Pertimbangan yang mendasari diambilnya responden yang relatif homogen, sehingga jumlah ini cukup representatif dalam memberikan informasi yang diperlukan. 


\section{Teknik Pengumpulan Data}

Pengunpulan data dalam penelitian ini dilakukan dengan mencari sumber- sumber literatul (referensi) berapa buku-buku, surat kabar dan artikel on-line yang sesuai dan terkait dengan pokok bahasa yang diangkat. Dalam pengumpulan data peneliti juga mengumpulkan data lapangan sebagai data yang valid dan dapat dipertanggung jawabkan serta mampu mewakili seluruh populasi yang diteliti. Dalam rangka memperoleh data yang akurat dari variable yang dikaji dalam penelitian ini, peneliti menggunakan teknik pengumpulan data berupa observasi, wawancara, dokumentasi, dan triangulasi.

\section{Teknik Analisis Data}

Analisis data yang digunakan dalam penelitian ini berlangsung bersamaan dengan poses pengumpulan data. Langkah-langkah yang ditempuh adalah:

a. Pengumpulan Data

Peneliti mencatat semua data secara objektif dan apa adanya sesuai dengan hasil observasi dan wawancara di lapangan. Hasil wawancara dan observasi di Rumah singgah Dukuh semar Kota Cirebon tentang "Peran Pembinaan Anak Jalanan Dinas Sosial Pemberdayaan Perempuan dan Perlindungan Anak di Rumah singgah Dukuh semar Kota Cirebon”. Seluruh data yang di dapatkan peneliti akan dimasukan ke dalam bank data dan akan diproses lebih lanjut.

Data-data yang disajikan dalam penelitian ini yaitu seperti aktifitas dalam pembinaan anak jalanan Dukuh semar Kota Cirebon.

b. Reduksi data

Proses penelitian, pemusatan penelitian pada penyerdarhanaan dalam transformasi data yang kasar yang muncul dicatatan tertulis di lapangan. Data yang diperoleh dari hasil penelitian "Peran pembinaan anak jalanan Dinas Sosial Pemberdayaan Perempuan dan perlindungan anak di Dukuh Semar Kota Cirebon", kemudian laporan atau data yang disusun berdasarkan data yang diperoleh direduksi, dirangkum, dipilih hal-hal yang pokok, difokuskan 
pada hal-hal yang penting, dan memilah-milih data terkait dengan pembinaan anak jalanan.

c. Penyajian data

Penyajian data dalam penelitian ini yaitu sekumpulan informasi tersusun memberi kemungkinan adanya penarikan kesimpulan dan pengambilan tindakan. Penyajian data yang digunakan dari penelitian ini yaitu dengan teks naratif sebagaimana yang diperoleh dari hasil wawancara dengan informan yaitu pembina anak jalanan dan anak jalanan Dukuh Semar Kota Cirebon.

d. Kesimpulan atau verifikasi

Kesimpulan atau varifikasi penelitian ini yaitu suatu kegiatan konfigurasi yang utuh. Setelah penelitian mengumpulkan data yang telah direduksi dan penyajian data dari dinas Sosial Pemberdayaan Perempuan dan PerlindunganAnak di Dukuh Semar Kota Cirebon terkait pembinaan anak jalanan, kemudian data yang diperoleh divarifikasi atau disimpulkan secara valid sehingga menjadi kesimpulan yang kredibel.

\section{HASIL PENELITIAN DAN PEMBAHASAN}

\section{Program Pembinaan Anak Jalanan Dinas Sosial Pemberdayaan Perempuan Di Rumah Singgah Dukuh Semar Kota Cirebon}

Rumah singgah Dukuh semar merupakan salah satu tempat pembianaan anak jalanan yang dibina oleh Dinas sosial pemberdayaan perempuan dan perlindungan anak untuk menangani kehawatiran yang akan terjadi terhadap anak jalanan yang sangat rawan terkena permasalahanpermasalah sosial, sehingga program-program Dinas sosial pemberdayaan perempuan dan perlindungan anak salah satunya menangani pembianaan terhadap anak jalanan agar anak-anak jalanan memiliki kehidupan yang lebih layak dan lebih baik dari sebelumnya. Adapun program-progam dalam pembinaan anak jalanan Dukuh semar antara lain yaitu, memberikan dukungan atau motivasi hidup agar lebih terarah, mengajarkan tatacara berwudu, sholat, mengaji al-qur'an, memberikan keterampilan untuk kehidupannya, memberikan arahan supaya hidup lebih bersih dan sehat 
sehingga kehidupan mereka atau anak jalanan jauh lebih baik dari sebelumnya.

Menurut hemat penulis program-program Dinas sosial pemberdayaan perempuan dan perlindungan anak dalam pembinaan anak jalanan sangat bagus karena untuk memajukan generasi anak dan bangsa karena diantaranya yaitu mengajarkan kehidupan yang baik dan memotivasi anak jalanan karena dilihat dari keseharian anak-anak jalanan terlihat sangat baik dan sopan dan anak-anak banyak yang masih melanjutkan pendidikamnya meski masih ada yang putus sekolah, dan anak-anak jalanan Dukuh semar sudah tidak seharian lagi berada di jalanan dan bahkan ada juga yang sudah tidak beraktivitas di jalanan lagi seperti mengamen, meminta-minta atau aktivitas ekonomi di jalanan lainnya, mereka sudah tidak di jalananan untuk berskolah dan menekuni karirnya.

\section{Proses Pembinaan Anak Jalanan Dinas Sosial Pemberdayaan Perempuan Di Rumah Singgah Dukuh Semar Kota Cirebon}

Sejak pertama lahir di dunia ini, manusia terus mengalami proses sosialisasi dengan lingkungan sekitarnya, pertama kalinya manusia bersosialisasi di dalam lingkungan keluarganya dimana manusia mendapatkan kasih sayang dan nilai-nilai dasar yang berguna untuk kehidupannya. Perkembangan ini selanjutnya mengarah pada sosialisasi lingkungan masyarakat dimana merupakan tempat beraktivitas dalam masa kanak-kanan, dengan keadaan orang tua yang kurang mampu dan didukung dengan lingkungan sekitar yang masih kurang maju dalam perekonomian bahkan tergolang ke dalam keluarga yang menengah kebawah sehingga kebutuhan pokok yang sulit terpenuhi, sehingga banyaknya kemunculan-kemunculan keluarga yang kurang layak kehidupannya sehingga munculah masalah sosial yang baru seperti anak jalanan. Untuk mencegah atau menanggulangi permasalah-permasalahan baru yang diakibatkan anak jalanan, maka perlu adanya pembinaan terhadap anak jalanan supaya anak jalanan memiliki kehidupan yamg lebih layak dan lebih baik dari sebelumnya.

Menurut hemat penulis pembinaan anak jalanan di Rumah singgah Dukuh semar Kota Cirebon program-programnya sudah sangat bagus untuk 
memajukan generasi anak dan bangsa, akan tetapi implementasi dari programprogram yang dikatakan dari Dinas sosial pemberdayaan perempuan dan perlindungan anak kurang berjalan secara maksimal karena dilihat apa yang dikatakan oleh para pekerja Dinas sosial pemberdayaan perempuan dan perlindungan anak atau pembina anak jalanan, pembinaan anak jalanan di Rumah singgah Dukuh semar dilaksanaka setiap hari sabtu, minggu dan harihari yang sudah terjadwalkan akan tetapi setelah peneliti mengamati lebih dalam proses pembinaan anak jalanan di Rumah singgah Dukuh semar tersebut Dinas sosial pemberdayaan perempuan dan perlindungan anak, setiap sabtu dan minggunya tidak terlihat dalam melakukan pembinaan anak jalanan di rumah singgah tersebut, sehingga implementasinya masih kurang berjalan secara maksimal.

\section{Peran Pembinaan Anak Jalanan Dinas Sosial Pemberdayaan Perempuan Di Rumah Singgah Dukuh Semar Kota Cirebon}

Peranan-peranan adalah kelengkapan dari hubungan-hubungan berdasarkan peran yang dimiliki oleh orang karena menduduki status-status sosial khusus. Selanjutnya dikatakan bahwa di dalam peranan tedapat dua macam harapan yaitu, pertama harapan-harapan dari masyarakat terhadap pemegang peranan atau kewajiban-kewajiban dari pemegang peranan terhadap masyarakat atau para pekerja sosial terhadap orang-orang yang berhubungan dengannya dalam menjalankan peranannya atau kewajiban-kewajibannya. Dalam pandangan David Berry, peranan-peranan dapat dilihat sebagai bagian dari struktur masyarakat dapat dilihat sebagai pola-pola pelayanan yang saling berhubungan. Identitas peran terdapat sikap tertentu dan prilaku aktual yang konsisten dengan sebuah peranan dan yang menimbuklkan identitas peran (role identify). Orang memiliki kemampuan untuk berganti peran dengan cepat ketika mereka mengenali terjadinya situasi dan tuntutan yang secara jelas membutuhkan perubahan besar.

Menurut hemat penulis peran-peran Dinas sosial pemberdayaan perempuan dan perlindungan anak di Rumah singgah Dukuh semar itu sudah cukup baik karena berdasarkan hasil wawancara dari berbagai pikak informen dan hasil pengamatan penelitidi dukung dengan peranan menurut David Berry 
dalam bukunya tahun 2003 Peranan-peranan adalah kelengkapan dari hubungan-hubungan berdasarkan peran yang dimiliki oleh orang karena menduduki status-status sosial khusus. Selanjutnya dikatakan bahwa di dalam peranan tedapat dua macam harapan yaitu, pertama harapan-harapan dari masyarakat terhadap pemegang peranan atau kewajiban-kewajiban dari pemegang peranan terhadap masyarakat atau para pekerja sosial terhadap orang-orang yang berhubungan dengannya dalam menjalankan peranannya atau kewajiban-kewajibannya.

Dalam pandangan David Berry, peranan-peranan dapat dilihat sebagai bagian dari struktur masyarakat dapat dilihat sebagai pola-pola pelayanan yang saling berhubungan. Identitas peran terdapat sikap tertentu dan prilaku aktual yang konsisten dengan sebuah peranan dan yang menimbuklkan identitas peran (role identify). Orang memiliki kemampuan untuk berganti peran dengan cepat ketika mereka mengenali terjadinya situasi dan tuntutan yang secara jelas membutuhkan perubahan besar. Karena itu peran Dinas sosial pemberdayaan perempuan dan perlindungan anak sudah cukup baik karena dapat dilihat dari keseharian anak-anak jalanan Dukuh semar, memiliki sopan santu memiliki etika yang baik, mampu mengubah pola pikir anak-anak jalanan, orang tua anak jalanan dan masyarakat atau lingkungan sekitar hingga menjadikan anak-anak jalanan lebih baik dari sebelumnya, yang awalnya seharian penuh hingga sekarang hanya beberapajam dan bahkan ada yang berhenti untuk tidak berada di jalanan dan lebih memilih untuk belajar untuk kehidupannya di masa akan datang. Alangkah lebih baik lagi jika programprogram pembinaan anak jalanan di Rumah singgah pemberdayaan perempuan dan perlindungan anak kegiatannya lebih di aktifkan lagi sehingga anak-anak tumbuh menjadi generasi-generasi bangsa yang baik, memiliki kemampuan dan keterampilan yang mampu di kuasai oleh anak-anak jalanan.

\section{E. KESIMPULAN DAN SARAN}

\section{Kesimpulan}

Berdasarkan hasil penelitian yang peneliti lakukan, maka dapat disimpulkan data dan uraian sebagai berikut : 
a. Program pembinaan anak jalanan di Dukuh semar kota Cirebon yang dilakukan Dinas sosial pemberdayaan perempuan dan perlindungan anak sudah sangat bagus karena dalam pembinaan itu diantaranya yaitu melakukan pembinaan dalam pembekalan ilmu agama seperti membaca al-qur'an, mengajarkan tata cara sholat, mengajarkan tata cara berwudhu yang benar, mengajakan kehidupan yang bersih dan sehat, memberikan dukungan supaya anak mau melanjutkan sekolah, memberikan keterampilan-keterampilan yang khusus untuk kehidupan anak jalanan, memberikan motivasi dalam kehidupan agar kehidupan anak jalanan jauh lebih baik dari sebelumnya.

b. Proses pembianana anak jalanan di Dukuh semar Kota Cirebon, prosesnya berjalan dengan cukup baik akan tetapi implementasinya masih kurang karena maksimal karena Dinas sosial pemberdayaan perempuan dan perlindungan anak setiap hari sabtu dan minngu tidak bisa menghadiri pembinaan anak jalanan di Rumah singgah Dukuh semar sehingga sangat menghambat dalam pembinaan dan masih belum maksimal karena masih ada anak yang putus sekolah dan lebih memilih bekerja dengan alasan membantu perekonomian orang tuanya, meski mereka yang putus sekolah ujarnya akan mengejar paket akan tetapi dampak dan perbedaannya akan terlihat dari diri anak tersebut.

c. Peran pembianaan anak jalanan di Dukuh semar Kota Cirebon yang dilakukan Dinas sosial pemberdayaan perempuan dan perlindungan anak, sudah baik karena menurut peneliti ketahui ada anak-anak yang sudah tidak sama sekali berada dijalanan, ada yang hanya setengah hari berada di jalanan, banyak anak-anak jalanan yang putus sekolah 2-3 tahun tetapi mereka masih mau melanjutkan sekolah meski ada yang kejar paket, banyak anak-anak yang diterima di sekolah negeri ternama yang berada di Kota Cirebon, tingkah laku dari anak-anak jalanan Dukuh semar yang baik dan mentaati orang tuanya dan menghormati yang lebih tua darinya, anakanak pernah merasakah hal-hal yang sama seperti anak pada umumnya cotohnya pada tahun sekitar 100 anak jalanan di kasih uang untuk berbelanja bareng di Giyant dan mereka membelanjakan uang itu dengan 
membeli kebutuhan gizinya seperti susu, biskuit dan membeli peralatan sekolah, pernah juga diadakan nonton bareng di XXI CSB mall itu mungkin waktunya sudah cukup lama sekitar 2-3 tahun dan yang diadakan ditahun ini yaitu akan diagendakan pada bulan maret 2018 yaitu outbound semua anak-anak jalanan kota Cirebon bersama pembina anak jalanan atau pekerja Dinas sosial pembersdayaan perempuan dan perlindungan anak. Alangkah lebih baiknya peran Dinas sosial pemberdayaan perempuan dan perlindungan anak lebih di aktifkan kembali untuk menciptakan generasi bangsa yang baik.

\section{Saran}

Berdasarkan hasil penelitian diatas, penulis menyampaikan beberapa saran dapat bermanfaat bagi semua pihak saran-sarannya antara lain yaitu:

a. Bagi Dinas sosial pemberdayaan perempuan dan perlindungan anak Perlu peningkatan dan lebih berkelanjutan tentang program dalam pembinaan anak jalanan dan mengubah pola pikir orang tua anak jalanan dan masyarakat sekitar, guna untuk menyelesaikan masalah anak jalanan.

b. Bagi Orang Tua Anak Jalanan

Anak adalah karunia dan amanah dari Allah saw yang dititipkan kepada orang tua, maka dari orang tua berkewajiban menjaga anak dan memberikan hak-hak anak.

c. Bagi Anak Jalanan

Menjadi anak jalanan bukanlah hal yang di inginkan namun ketiadaan perekonomian orang tua memaksa anak jalanan harus bekerja untuk menyambung hidup, menjadi anak jalanan bukanlah pekerjaan yang hina namun keberadaan dan status anak jalanan kurang mencerminkan untuk generasi bangsa, oleh karena itu anak jalanan tidak seharusnya berada seharian penuh di jalanan alangkah lebih baiknya anak-anak jalanan lebih difokuskan lagi dalam dunia pendidikan dan mencari keahlian-keahlian atau keterampilan yang di sukai agar kehidupan anak-anak jalanan lebih baik lagi di masa akan datang karena masa depan itu di bentuk hari ini bukan nanti atau berapa tahun lagi. 


\section{DAFTAR PUSTAKA}

Bajari, Atwar. (2012). Anak Jalanan Dinamika Komunikasi dan Prilaku Anak Menyimpang. Bandung: Rikrir Wirasetiadi.

Berry, David. (2003). Pikiran dalam Sosiologi, Jakarta: Raja Grafiindo Persada.

Gultom, Maidin. (2014). Perlindungan Hukum Terhadap Anak dalam Sistem Peradilan Pidana Anak di Indonesia. Bandung: Rafika Aditama.

Moleong, Lexy J. (2011). Metodologi Penelitian Kualitatif. Bandung: Rosdakarrya.

Munaf. (2000). Manaemen Kepegawaian di Indonesia. Jakarta: Haji Masagung.

Rustanto Bangbang. (2015). Penelitian Kualitatif Pekerjaan Sosial. Bandung: Remaja Rosdakaya.

Suyono Haryono. (2003).Ekonomi Keluarga Pilar Utama Keluarga Sejahtera. Jakarta: Yayasan Damandiri.

Toha, Miftah. (2001). Pembinaan Organisasi. Jakarta : Raja Grafindo Persada. 
